\title{
ASSESSMENT OF TOURISTS’ SATISFACTION IN THE DOWNTOWN OF AMMAN
}

\author{
Monther M. Jamhawi* - Jordan University of Science and Technology \\ Nada Al-Shakarchi ${ }^{+}$- Jordan University of Science and Technology \\ Imad Al-Hashimi* - Jordan University of Science and Technology
}

Tourist satisfaction is considered as one of the most important aspects of sustainable tourism, as it considerably impacts on the tourist's length of stay and on their choice to visit the destination in the future. This research focused on making an assessment for several attributes related to tourists' satisfaction in Amman downtown in Jordan. The study attempts to investigate the relationship between tourists' experience in downtown Amman and their overall satisfaction level in terms of services quality, spatial movement, local hospitality, tourists' enjoyment and comfort, and the quality of urban environment around.

Keywords: tourism; tourists’ satisfaction; sustainable development; tourism indicators; downtown Amman

Qualitative and quantitative data was collected through field observation, interviews and structured questionnaires. The results showed that local hospitality had the highest positive impact on the tourists' satisfaction in downtown Amman, while the spatial movement and traffic jams had a negative influence. Therefore, some recommendations have been proposed that are mainly relied on the need to enhance tourists' movement, landscaping, signage, and transportation availability, in addition to the need to provide shaded areas and some other cultural activities around.

\section{INTRODUCTION}

Tourism has grown spectacularly to be one of the remarkable phenomena in the twentieth century; it became a global economic and social force. Indeed, tourism has experienced continued growth and deepening diversification to be a key driver for socioeconomic progress, and a main contributor in the well-being of communities. ${ }^{1}$ However, this contribution depends on the quality and the revenues of the tourism offer.

Tourists' satisfaction is one of the most investigated topics in the tourism and hospitality industry due to its influence on the sustainability of tourism services. ${ }^{2}$ Tourists' satisfaction is crucial for the visitor decision to return, ${ }^{3}$ it is considered as a key indicator of long-term sustainability for any touristic destination. ${ }^{4}$ Tourist satisfaction measures the

* Department of City Planning and Design at the College of Architecture and Design in Jordan University of Science and Technology. P.O. Box 3030, Irbid 22110, Jordan. Tel.: +962 (0) 2 7201000. Mob.: +962 (0) 795662533. E-mail: mjamhawi@just.edu.jo.

+ Graduate Student, Department of City Planning and Design, College of Architecture and Design, Jordan University of Science and Technology, graduated on 2011.

1 UNWTO 2015

2 Kozark - Rimmington 2000.

3 Kozark - Rimmington 2000; WTO 2004.

4 WTO 2004 
perceptions, expectations, complaints and problems ${ }^{5}$ regarding quality of provided tourist facilities, ${ }^{6}$ such as accommodation cleanliness, water and food safety, hospitality and others, ${ }^{7}$ as well as, attractiveness and authenticity of the destination that form the main motivation to visit one destination more than other. ${ }^{8}$ Due to the subjectivity of impressions, it is hard to measure tourist satisfaction accurately, ${ }^{9}$ so a detailed deep analysis is required to evaluate visitor satisfaction that in turn will reflect in their behaviors. Indeed, many studies stressed the fact that tourist satisfaction has a positive impact on the behavior of tourists. ${ }^{10}$

Many efforts have merged in researches to explore tourists' satisfaction impacts on tourism, given to the important role that these impact "indicators" play in enhancing their tourism experience and mitigate the negative effects. These indicators are measurements such as the percentage of return visitors, percentage of tourists satisfied with the destination, percentage of tourist expectations met, complaints received, and others. Measuring tourists' satisfaction plays an important role in marketing tourism products and services in any touristic destination. S. Tian-Cole and J.L. Crompton (2003) pointed out that «satisfaction levels are determined after service consumption. It is often referred to as post service evaluation, an emotional state of mind which involves consumers' feelings about an experience and not the real quality of services». ${ }^{11}$

Jordan is very rich in cultural and archaeological heritage; many natural wonders and particularly welcoming people makes tourism a key driver of the economy. Jordan's reputation as a safe country within a region of many conflicts had a positive impact on the tourism industry in the country. The annual income growth from tourism through the last fifteen years has encouraged the government of Jordan to invest more in tourist infrastructure. ${ }^{12}$

Culture and history are usually found in the old city centers, which proved to be one of the major tourism attractions. Accordingly, the importance of evaluating tourists' satisfaction in Amman downtown was raised. Such evaluation will lead to investigate the positive and negative variables, which have impact on the tourism industry. This would help in identifying visitors' perception toward the performance of the different service sectors, as well as the destination attractiveness.

Two aspects were considered in order to be measured in this study, these are:

1. Service quality which is defined as the purchase package of the tourism industry in addition to the intangible elements conjugated with that need to be assessed to determine the level of satisfaction. ${ }^{13}$

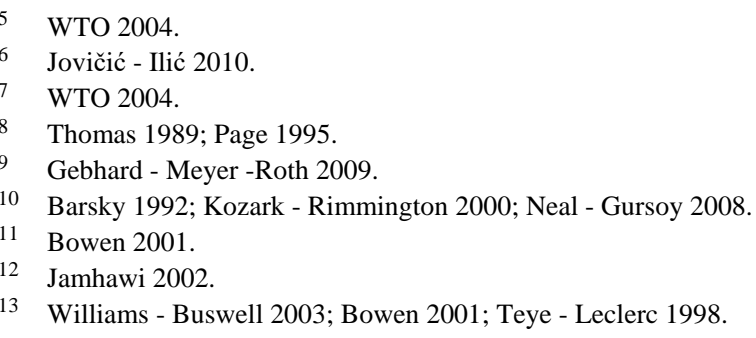


2. Tourists' destination which is defined as a country, region or city to which tourists travel and at which they do not usually reside. A tourist destination has the following properties:

- Attractions and facilities that appeal to tourists.

- It is readily accessible via the transport mode tourists prefer.

- It is affordable.

- It projects an image in line with tourists' needs and preferences. ${ }^{14}$

The main question for this research was "How much the tourists in Amman downtown are satisfied with their visit?", and "What are the main factors affecting; negatively or positively, their experience?”

\section{STUDY AREA "DOWNTOWN OF AMMAN"}

The historic downtown of Amman "al-Balad" is one of the major tourism destinations in Jordan (fig. 1). It is known by its steep topography located on the valley of the ancient river of Amman (Seil Amman). Moreover, Amman downtown has a unique landscape with hills and valleys connected by stairs and rounded roads. Now a day, it is full of shops, restaurants and historical sites. Amman downtown includes 7 neighborhoods with total of 1,840 dunams. It is considered the center of business district of Amman city up to the late 70 's or 80 's of last century.

Amman downtown witnessed the presence of many civilizations: Hellenic, Nabataean and Roman, Byzantines, and Umayyads. Its heritage is dated to at least $6700 \mathrm{BC}$, while what is now known by al-Balad emerged after 1200 BC. Amman downtown also was part of the Roman Decapolis city network where many traders and acting troupes passed through as it was considered one of the main thriving oasis on their way.

Hundreds of Stairs link the downtown area with the acropolis in the Amman Citadel. The Citadel of Amman is a holy site served as a place for worship and sacrifice for the people of the city for more than 2000 years. Moreover, the area's long history leaves a large number of historical sites, such as the Umayyad city and some other Roman and Byzantine monuments at the citadel, the Roman theater, Nymphaeum, and the Odeon theater down near the Hashemite Plaza.

The richness and the diversity of Amman, including the downtown, attracted approximately 1.9 million visitors in 2014, which made it the $4^{\text {th }}$ most visited Arab city, and the ninth highest recipient of international visitor spending (Euro monitor 2015).

\section{Methodology}

The study considered the service sectors suggested by K. Chon (2009), who investigated the sectors that may have impact on tourist's satisfaction, which are: attractions, hotels, restaurants, retail shops and transportation. On the other hand, the study adopted the classification made by the Ministry of Tourism and Antiquities MOTA (2005) to understand the context of Amman downtown. The classification includes the following themes: community facilities, roads and transportation, archaeology and heritage context, environment and natural context.

14 Bennett 2000 
The data was collected using field observations and structured questionnaire. The questionnaire targeted 210 visitors in Amman Downtown during spring/summer 2010. The responses were 150 (fig. 3) which equals to 71\%. Interviews and previous studies were also used to support the results and to know about the current situation of tourists' satisfaction in the study area.

The data variables were analyzed under 2 categories: dependent and independent variables. The dependent variable is the level of tourist satisfaction, while the independent variables were divided into five categories, see figure 2. A correlation between the variables was figured out using SPSS software (correlation and regression analysis).

The following equation (tab. 1) was followed to calculate the linear regression in SPSS software and to test the different variables (dependent and independent) and to create relations between them:

\begin{tabular}{|l|l|}
\hline \multicolumn{2}{|c|}{$\mathrm{Y}=\mathrm{a}+\mathrm{b} \mathrm{X}+\mathrm{b} 1 \mathrm{X} 1+\mathrm{b} 2 \mathrm{X} 2+\mathrm{b} 3 \mathrm{X} 3+\ldots$} \\
\hline $\mathrm{Y}$ & Satisfaction which represents the dependent variable \\
\hline $\mathrm{A}$ & Constant \\
\hline $\mathrm{B}$ & (t) testing value which indicates the independent variable significance \\
\hline $\mathrm{X}$ & the independent variable value \\
\hline
\end{tabular}

Tab. 1 - The equation used to calculate the linear regression in SPSS (Statistical Program for the Social Sciences) software.

The coefficient of determination was applied to report the variation in percentages of independent variables. T-tests were utilized to reveal the significance of the identified independent variables on the individual independent variables. On the regression model, the F-test was utilized to reveal the significance of the identified independent variables on the individual independent variables.

\section{RESULTS AND DISCUSSION}

The results showed that the nationalities of the respondents varied between international (73\%) and regional tourists (27\%). For international tourists visiting Amman downtown, it can be noted that the largest segment came from Europe (65\%), followed by America (25\%) and Asia (10\%). While for regional visitors, 35\% of respondents were locals, followed by $10 \%$ from Gulf countries, and the rest $(65 \%)$ of came from other Arab countries.

Among the different nationalities surveyed, it was found that most of the Arab preferred 4-star and 5-star hotels whereas most of the international tourists stayed in 3-star and nonhotel accommodation. This could be because the international visitors are more interested in experiencing the traditional life in the destination as this is their main motivation to visit this attraction. While for visitors coming from Arab countries (mainly from the golf countries), they usually visit Amman including the downtown to spend their summer vacation and enjoy the moderate weather in Jordan where they are looking for luxury and high quality services. Generally, it was found that most of the visitors were motivated to travel for leisure purposes. 
Figure 3 describes the general characteristics of respondents. It can be noted that $53 \%$ of tourists were on their first visit to the Downtown of Amman, while 47\% were repeat visitors.

Tourists were asked to rate the expectations of the destination attributes on a Likert Scale (1 strongly disagree - 10 strongly agree). Table 2 reveals the performance of the destination attributes as perceived by the visitors during their visit. The results were categorized into 2 groups of attributes; satisfactory and dissatisfactory. The plus sign (+) represents the level of satisfaction while the minus (-) represents the level of dissatisfaction that was measured for each attribute.

The highest mean value related to "local hospitality", followed by "attractive trails" and "reasonable price", with performance scores of 9.8, 9.4 and 8.6 respectively. Also, the interaction of tourists and locals was a factor which affected tourist satisfaction with the destination. While the "movement and walkability" and "crowed and traffic" obtained the lowest score for expectations. Additionally, the road signage along roads was not clear and independent visitors could easily get lost.

Most of the international visitors for the downtown were interested with cultural activities and historical sites; however, the results revealed that they were not satisfied with the offered activities in the destination. Although most of targeted samples preferred experiencing the place on foot, they had complains with regard to the quality of sidewalks and the availability of sheltered areas.

Attributes such as "restaurants and cafes facilities", "attractive sites”, and "quality of hotels" were rated with mean scores between 7 and 6.1. However as illustrated in Table 2, the attributes "cleanliness", "entertainment” and "safety” were not statistically significant.

\begin{tabular}{|c|c|c|c|c|c|}
\hline & & & & & \\
\hline c & Movement/walkability & -8.5 & Hospitality & 9.8 & \\
\hline & Crowding & -8.2 & Tour guides and roots & 9.4 & \\
\hline 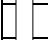 & Lack of shading areas & -7.7 & Friendliness of locals & 8.7 & \\
\hline 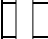 & Accessibility & -7.6 & Reasonable prices & 8.6 & \\
\hline 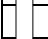 & Transportation & -7.2 & Cafes and restaurants & 7 & \\
\hline 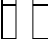 & Spirit of place & -6.3 & Attractive sites & 6.5 & \\
\hline 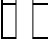 & Pollution & -6.1 & Quality of hotels & 6.1 & \\
\hline 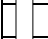 & Shopping facilities & -5.8 & Social activities & 4.7 & \\
\hline H & Cleanliness & -4.4 & & & \\
\hline$\Gamma$ & Entertainment & -3.6 & & & \\
\hline & Safety & -2.5 & & & \\
\hline
\end{tabular}

Tab. 2 - Performance of the destination attributes in Amman downtown.

The $(\mathrm{t})$ coefficient testing revealed that the $\mathrm{R}^{2}$ reliability was about $53.6 \%$. The study also investigated tourist overall satisfaction with the destination, which was positive as the overall score was 7.4 out of 10 . Table 3 clarify the descriptive evaluation for this scoring which relied on the SERV-QUAL scale to evaluate the tourist satisfaction with the destination attributes. 


\begin{tabular}{|c|l|}
\hline $10-9$ & Very satisfactory \\
\hline $8-7$ & Satisfactory \\
\hline $6-5$ & Average satisfaction \\
\hline $4-3$ & Unsatisfactory \\
\hline $2-1$ & Very unsatisfactory \\
\hline
\end{tabular}

Tab. 3 - Level of satisfaction out of 10 on Likert scale.

\section{CONCLUSIONS}

The data collected in this study provided important information regarding tourist satisfaction at the destination under scrutiny (fig. 4). The SERV-QUAL scale and SPSS software used in the study has investigated tourist satisfaction across 19 destinations attributes as well as the overall satisfaction with the destination.

Tourists' satisfaction with individual destination attributes reveals that 8 attributes were positively evaluated. The highest positive assessment occurred with "local hospitality" and "attractive roots". On the other hand, 11 destination attributes were negatively assessed as they fall below the expectations of tourists. These attributes were mainly related to the spatial movement of tourists in the downtown of Amman, due to the crowded spaces, unavailability of sufficient pedestrian paths and crossings, and bad accessibility. Tourists' dissatisfaction is also further explained by the unclean environment of the destination and the traffic that spoil the spirit of place. This is in addition to the lack of shaded areas, noise and pollution. However, the overall satisfaction with the destination was positive with overall score 7.4 out of 10 .

This study has helped to identify the weak attributes of the destination, where a particular attention should be spent to improve the destination and meet the expectations of visitors and motivate them to visit it again.

\section{RECOMMENDATIONS}

As a result of this study and to improve the tourism experience in Amman downtown, a set of recommendations are suggested. These are including but not limited to the following:

1. Strengthening transportation linkages:

a. Encouraging more compact development in urban areas.

b. Planning for an investment program in the destination that aims at improving the infrastructure and providing new regulatory and fiscal tools to attract growth.

2. Providing parking structures/spaces outside the downtown such as Ras el-Ain area, and apply a policy that prevents parking along the Hashimi and Quraishi streets.

3. Providing wider and clear pedestrian crossing strips with clear signs along the Hashimi Street.

4. Reforming existing alleyways, while giving special attention to stairs and handrails.

5. Encouraging planting over roofs and along the houses adjacent to the stair alleys.

6. Widening the pavements to improve pedestrian movement.

7. Providing shading areas and louvers along the passages and open spaces.

8. Enhancing the lighting along the route leading from downtown to the citadel of Amman. 
9. Ensuring the cleanliness of the area especially near the markets area.

10. Restoring the old abandoned houses and maintain their structures and architectural details.

11. Improving the quality of hotel's services and cleanness.

\section{REFERENCES}

BARSKY, J.D.

1992 Customer satisfaction in the hotel industry: meaning and measurement: Hospitality Research Journal 16 (1992), pp. 51-73.

BENNETT, J.A. (ed)

$2000 \quad$ Managing Tourism Services. Southern African Perspective, Hatfield 2000.

BOWEN, D.

2001 Antecedents of consumer satisfaction and dissatisfaction on Long-haul inclusive tours - a reality check on theoretical considerations: International Journal of Tourism Management 22 (2001), pp. 49-61.

CHON, K.

2009 PolyU Tourist Satisfaction Index (The Hong Kong Polytechnic University), Hong Kong 2009.

Gebhard, K - Meyer, M. - Roth, S.

2009 Criteria for Sustainable Tourism for the three Biosphere Reserves Aggtelek, Babia Góra and Šumava, Bonn 2009.

JAMHAWI, M.M. AL-DAHASH

2002 Conservation and Tourism: Jordan's Post 18th Century Architectural Heritage, PhD Diss. Oxford Brookes University, Oxford 2002.

JoviČIĆ, D. - ILIĆ, T.

2010 Indicators Of Sustainable Tourism: Serbian Geographical Society 90 (2010), pp. 277-305.

KOZARK, M. - RIMMINGTON, M.

2000 Tourist Satisfaction with Mallorca, Spainas an Off-Season Holiday Destination: Journal of Travel Research 38 (2000), pp. 260-269.

MinistRy OF TOURISM AND ANTIQUITIES (MOTA)

2004-2010 National Tourism Strategy, Amman 2004-2010.

2005 Detailed Description of the City Revitalization Program. Madaba, Amman 2005.

2015 City revitalization program, Amman 2015.

NEAL, J.D. - GURSOY, D.

2008 A multifaceted analysis of tourism satisfaction: Journal of Travel Research 47 (2008), pp. 53-62.

PAGe, S.

$1995 \quad$ Urban Tourism, London1995.

TEYE, B.V. - LECLERC, D.

1998 Product and Service Delivery Satisfaction Among North American Cruise Passengers: International Journal of Tourism Management 19 (1998), pp. 153-160.

THOMAs, C.

1989 The roles of historic sites and reasons for visiting. Heritage Sites: D.T. HERBERT - R.C. Prentice - C.J. ThomAs (eds.), Strategies for Marketing and Development, Avebury 1989), pp. 62-93. 
ToP 100 InTERnational TOuRIST Destination Cities By Country. Euromonitor. http://brilliantmaps.com/. 2015-01-24.

Tian-Cole, S. - CRompton, J.L.

2003 A conceptualization of the relationship between service quality and visitor satisfaction, and their links to destination selection: Leisure Studies Journal 22 (2003), pp. 65-80.

UNITED NATIONS WORLD TOURISM ORGANIZATION (UNWTO)

2015 Tourism highlights, Madrid 2015.

WORLD TOURISM ORGANIZATION (WTO)

2004 Indicators of Sustainable Development for Tourism Destinations. A Guidebook, Madrid 2004.

WiLLiAMS, C. - BuSWELL, J.

2003 Service Quality in Leisure and Tourism, Wallingford 2003. 


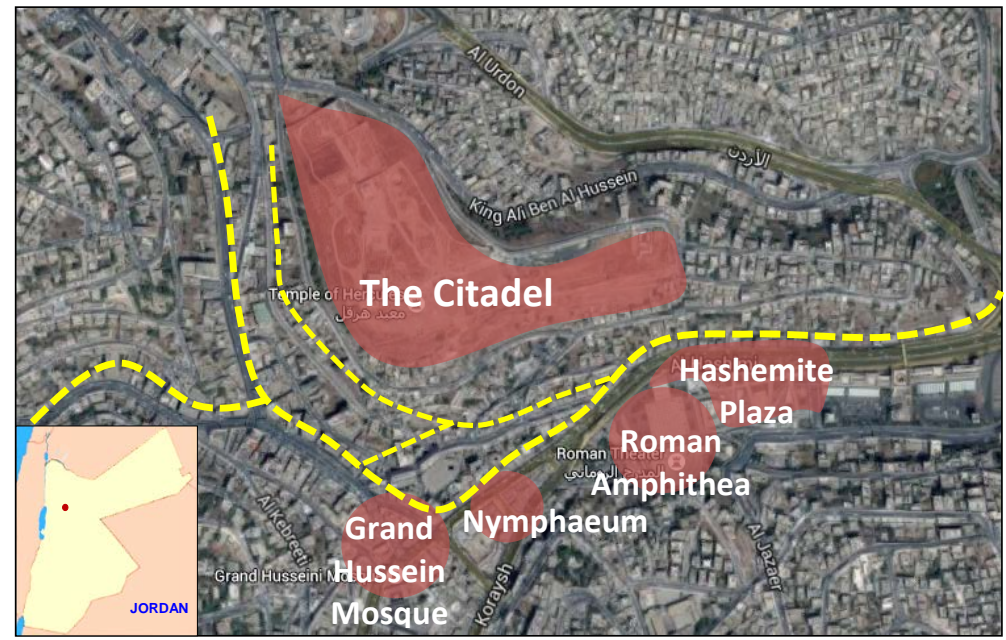

Fig. 1 - A map for Amman Downtown with the main tourists’ attractions (MOTA 2004).

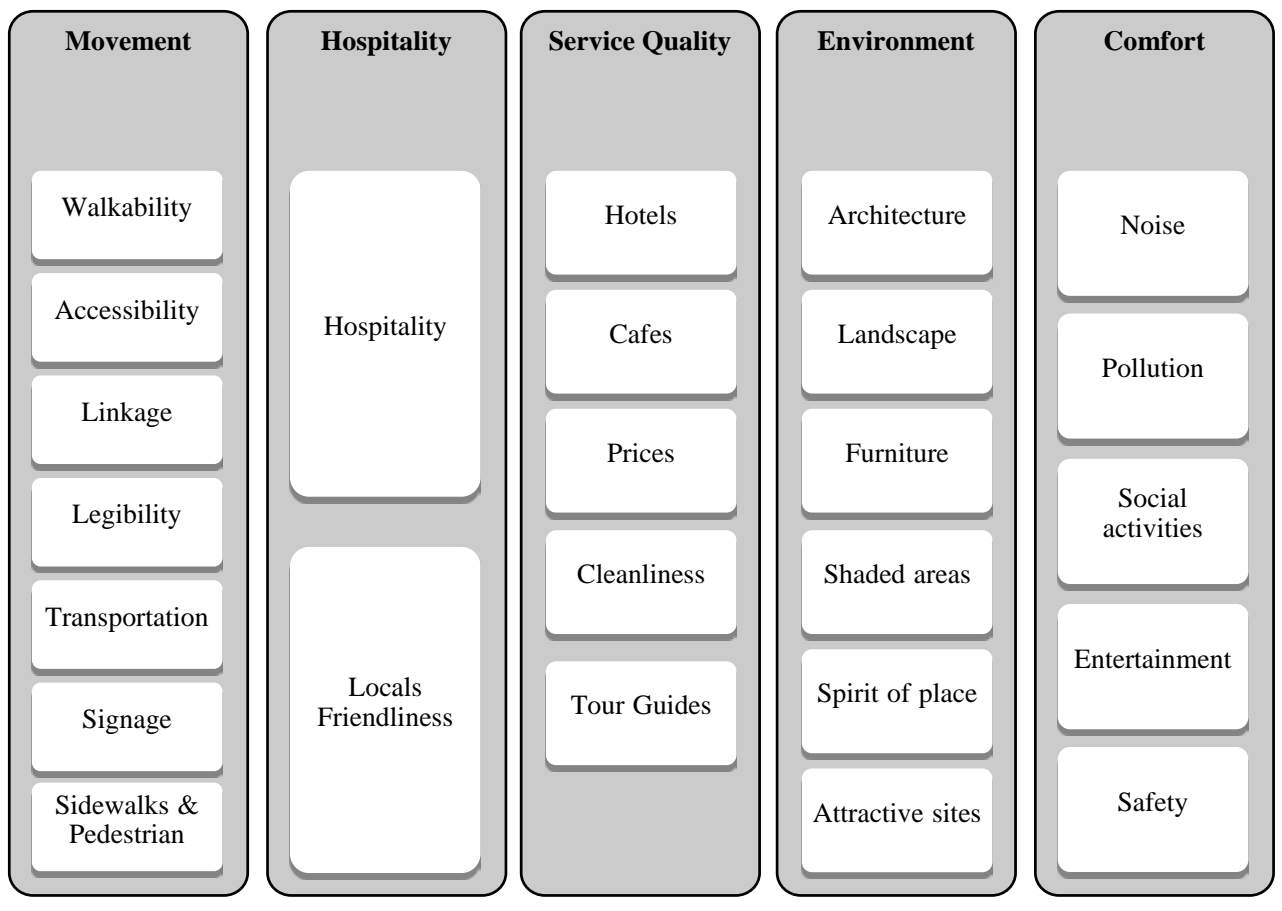

Fig. 2 - Independent variables categories. 


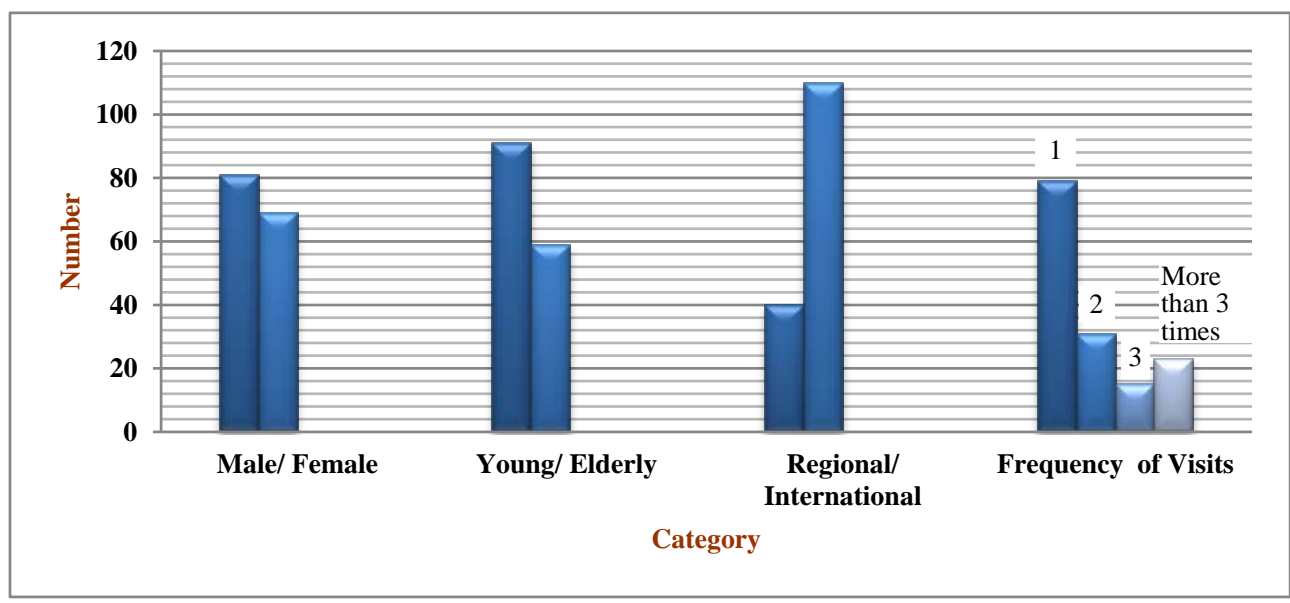

Fig. 3 - Tourists' characteristics $(n=150)$.

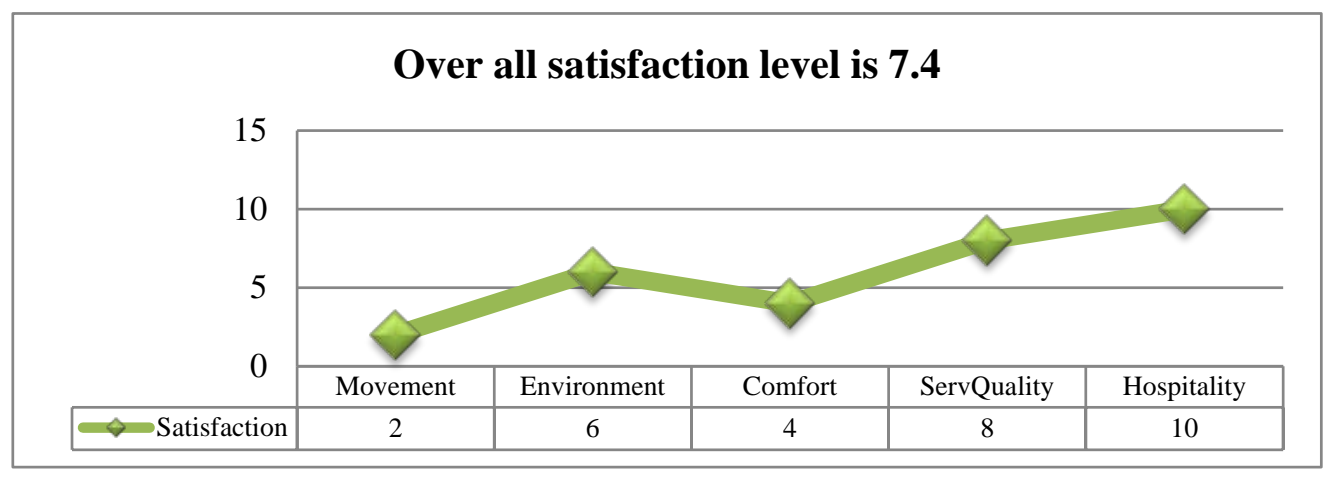

Fig. 4 - Overall tourists' satisfaction in Downtown Amman. 


\section{SOMMARIO}

DipartimENTo SCIENZE DELl'ANTICHITÀ

SEZIONE di ORIENTALISTICA

\section{VICINO ORIENTE \\ XIX - 2015}

L. Nigro - Bethlehem in the Bronze and lron Ages
in the light of recent discoveries by the Palestinian MOTA-DACH

$\checkmark$. Pisaniello - Parallel passages among Hittite-Luwian rituals:

for the restoration of $K U B 35.146$

F. Spagnoli - Una testa di sileno in bronzo da Mozia

N. Chiaren

dall Area sacra del Kothon a Mozia

G. Labisi - al-Fudayn: an Umayyad residence in Northern Jordan

P. Buzi - Early Christianity in the Fayyūm: the new contribution of archaeology

I. Materia - Preliminary notes on the ware depicted on the ceiling

of the Cappella Palatina in Palermo

S. Autiero - Indian Ocean trade:

a reassessment of the pottery find
$\left(3^{\text {rd }}\right.$ century $B C-S^{S^{t h}}$ century $\left.A D\right)$

M.M. Jamhawi - N. Al-Shakarchi - I. Al-Hashimi

Assessment of tourists' satisfaction in the downtown of Amman

SCAVI E RICERCHE

L. Nigro - C. Fiaccavento - M. Jaradat - J. Yasine

A

L. Nigro - D. Montanari - M. Ghayyada - J. Yasine

A Middle Bronze and Iron Age necropolis near Bethlehem (Palestine)

L. Nigro - G. Ripepi - I. Hamdan - J. Yasine

15 Interim Report

and valorization of archaeological heritage

R. Francia - L'archivio di tavolette del complesso B-C-H di Büyükkale

organizazione degli archivi reali ittiti. Considerazioni preliminari

V. Pisaniello - La collezione di tavolette del complesso B-C-H di Büyükkale

T. De Vincenzi - L'archivio di tavolette del complesso B-C-H
sull'acropoli di Büyükkale

Museo del Vicino Oriente, Egitto e Mediterraneo

L. Nigro - Il nuovo allestimento del Museo del Vicino Oriente,

Egitto e Mediterraneo della Sapienza

D. Montanari - Bollettino delle attività del Museo del Vicino Oriente,

Egito e Meditraneo della Sapienza, anno 2015

RECENSIONI

A. Orsingher - E. PAPPA (2013), Early Iron Age Exchange in the West:

(Ancient Near Eastern Studies Supplement Series 43)

Leuven - Paris - Walpole 2013, MA.: Peeters $\frac{1}{2}$

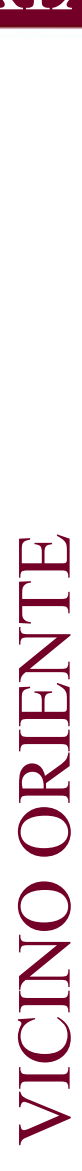

345

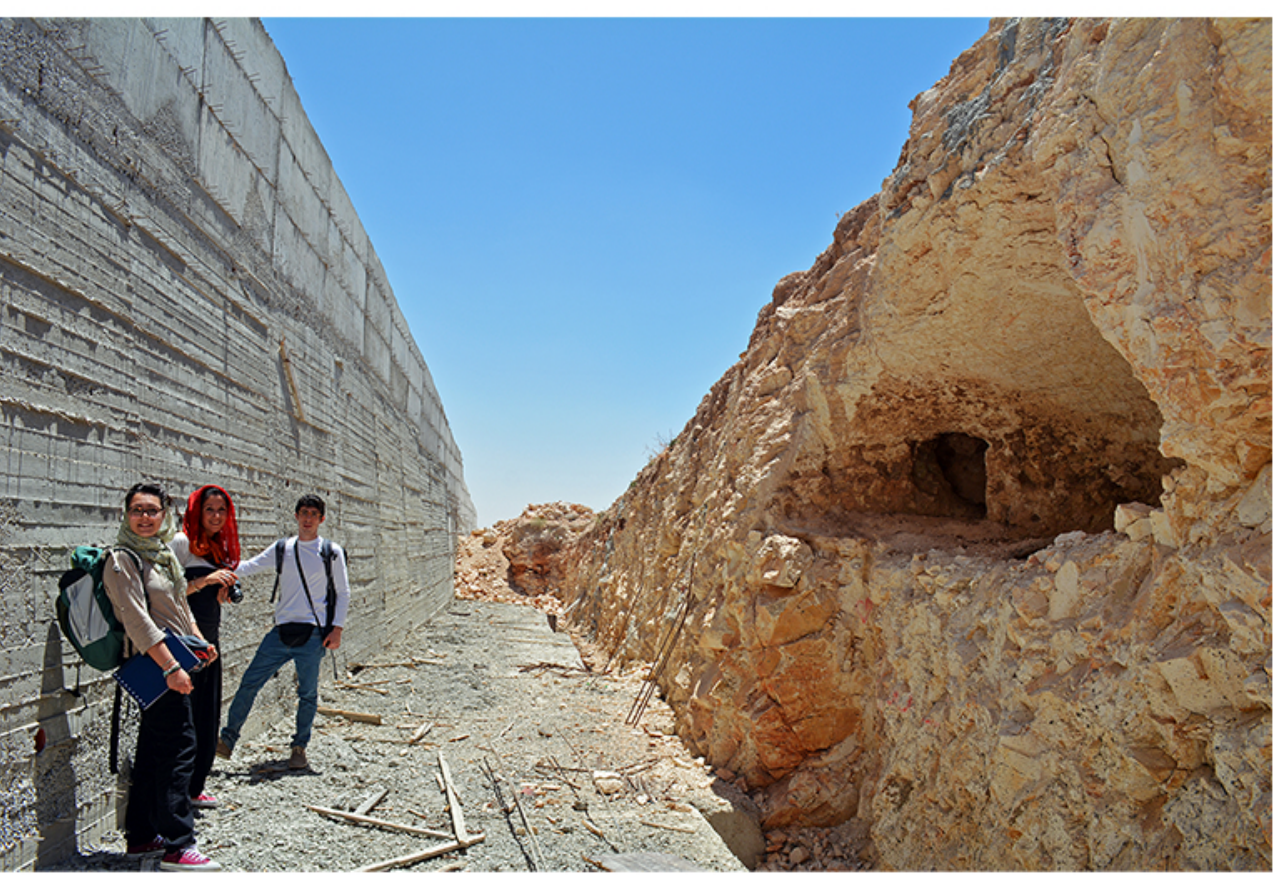

ROMA 2015 


\section{VICINO ORIENTE XIX - 2015}


VICINO ORIENTE

SAPIENZA UNIVERSITÀ DI ROMA

DIPARTIMENTO SCIENZE DELL'ANTICHITÀ

SEZIONE DI ORIENTALISTICA

Scientific Editor: Lorenzo Nigro

International Scientific Committee: Brian Rose, Frank Braemer, Mounir Fantar, Piero Bartoloni, Thomas Schaefer, Zeidan Kafafi

National Scientific Committee: Carlo Giovanni Cereti, Maria Vittoria Fontana, Sebastiano Tusa, Massimiliano Marazzi

Editorial Board: Daria Montanari, Chiara Fiaccavento

Tipografia: SK7 - Roma

ISSN 0393-0300

Rivista con comitato di referee

Journal with international referee system

www.lasapienzatojericho.it/SitoRivista/Journal/Rivista.php

In copertina: Tomba B9, necropoli di Khalet al-Jam’a (Betlemme). 
VICINO ORIENTE

SAPIENZA UNIVERSITÀ DI ROMA

DIPARTIMENTO SCIENZE DELL'ANTICHITÀ

SEZIONE DI ORIENTALISTICA

\section{SOMMARIO}

ARTICOLI

L. Nigro - Bethlehem in the Bronze and Iron Ages

in the light of recent discoveries by the Palestinian MOTA-DACH

V. Pisaniello - Parallel passages among Hittite-Luwian rituals:

for the restoration of KUB 35.146

F. Spagnoli - Una testa di sileno in bronzo da Mozia

N. Chiarenza - Una matrice per terrecotte con sileno dall'Area sacra del Kothon a Mozia

G. Labisi - al-Fudayn: an Umayyad residence in Northern Jordan

P. Buzi - Early Christianity in the Fayyūm: the new contribution of archaeology

I. Materia - Preliminary notes on the ware depicted on the ceiling

of the Cappella Palatina in Palermo

S. Autiero - Indian Ocean trade:

a reassessment of the pottery finds from a multidisciplinary point of view ( $3^{\text {rd }}$ century $B C-5^{\text {th }}$ century $\left.A D\right)$

M.M. Jamhawi - N. Al-Shakarchi - I. Al-Hashimi

Assessment of tourists' satisfaction in the downtown of Amman

SCAVI E RICERCHE

L. Nigro - C. Fiaccavento - M. Jaradat - J. Yasine Archaeology from A to Z: Abu Zarad, an ancient town in the heartland of Palestine

L. Nigro - D. Montanari - M. Ghayyada - J. Yasine

Khalet al-Jam'a. A Middle Bronze and Iron Age necropolis near Bethlehem (Palestine) 185 
VICINO ORIENTE

SAPIENZA UNIVERSITÀ DI ROMA

DIPARTIMENTO SCIENZE DELL'ANTICHITÀ

SEZIONE DI ORIENTALISTICA

L. Nigro - G. Ripepi - I. Hamdan - J. Yasine

The Jericho Oasis Archaeological Park - 2015 Interim Report.

Italian-Palestinian Cooperation for protection

and valorization of archaeological heritage

R. Francia - L'archivio di tavolette del complesso B-C-H di Büyükkale

e l'organizzazione degli archivi reali ittiti. Considerazioni preliminari

V. Pisaniello - La collezione di tavolette del complesso B-C-H di Büyükkale

T. De Vincenzi - L'archivio di tavolette del complesso B-C-H sull'acropoli di Büyükkale

Museo del Vicino ORIente, Egitto e MediterRaneo

L. Nigro - Il nuovo allestimento del Museo del Vicino Oriente,

Egitto e Mediterraneo della Sapienza

D. Montanari - Bollettino delle attività del Museo del Vicino Oriente,

Egitto e Mediterraneo della Sapienza, anno 2015

\section{RECENSIONI}

A. Orsingher - E. PAPPA (2013), Early Iron Age Exchange in the West:

Phoenicians in the Mediterranean and the Atlantic

(Ancient Near Eastern Studies Supplement Series 43),

Leuven - Paris - Walpole 2013, MA.: Peeters 